\title{
Koncepcja integralnego rozwoju osoby według Karola Wojtyły kluczem do rozumienia dramatu moralnego człowieka
}

\author{
Karol Wojtyła's concept of integral development of \\ a person - the key in understanding moral drama of a man
}

\begin{abstract}
STRESZCZENIE:
Celem artykułu jest ukazanie znaczenia koncepcji integralnego rozwoju osoby według Karola Wojtyły dla rozumienia dramatu moralnego człowieka, który niejednokrotnie

staje wobec konfliktu wewnętrznego

przyjmującego postać dramy. To, co „dzieje

się" w człowieku i to, co z nim „dzieje

się", stanowi wartość dynamizującą jego

rozwój, o ile jego sumienie jest właściwie ukształtowane i jest on zdolny do refleksyjno-

-konstruktywnego przeżywania siebie w przestrzeni dramowej własnego „teatru wnętrza".

SŁOWA KLUCZOWE:

integralny rozwój osoby, drama, dramat moralny, refleksja, sumienie
\end{abstract}

\begin{abstract}
:
Article is aimed at showing the meaning of concept of integral development of a person according to Karol Wojtyła for understanding man's moral drama. The man often faces up the inner conflict that takes the shape of drama. What happens in man and what happens with man is a value that makes his development dynamic, provided that his conscience is appropriately formed and he is able to experience himself in his drama space of own "interior theatre" in reflective and constructive way.
\end{abstract}

\section{KEYWORDS:}

integral development of a person, drama, moral drama, reflection, conscience

\section{WPROWADZENIE}

Przedstawienie koncepcji integralnego rozwoju osoby według Karola Wojtyły jako klucza do rozumienia dramatu moralnego ma na celu wyłonienie istotnych uwarunkowań popełnianego czynu w świetle antropologiczno-aksjologicznym oraz psychologiczno-pedagogicznym. Wymaga też wskazania na pozytywne 
i negatywne dynamizmy kształtowania się środowiska wewnętrznego człowieka. Realizacja tego celu skłania ku odniesieniu się do zagadnień nadających tej koncepcji interdyscyplinarnego charakteru. Są nimi:

- personalistyczna teoria integralnego rozwoju i wychowania Stefana Kunowskiego, kompatybilna do koncepcji integralnego rozwoju i wychowania według Karola Wojtyły;

- koncepcja kształtowania się środowiska życia wewnętrznego w ujęciu Kazimierza Dąbrowskiego;

- ujęcie moralnej tożsamości samego siebie według Daniela K. Lapsley’a i Darci Narvaez'a;

- ujęcie dramy według Grażyny Zielińskiej.

Analiza wymienionych zagadnień stanowi jedynie zasygnalizowanie podejmowanej tematyki, której ujęcie wydaje się być nowatorskie w świetle dokonanego przeglądu literatury przedmiotu. Celem niniejszego opracowania jest także ukazanie złożoności istoty dramatu moralnego człowieka, jego dynamiki, jako że nie jest to bez znaczenia dla osiągania dojrzałości moralnej. Realizacja wspomnianych celów implikuje konieczność postawienia problemu badawczego. Zawiera się on w pytaniu: czy koncepcja integralnego rozwoju według Karola Wojtyły może być traktowana jako „klucz” do rozumienia dramatu moralnego człowieka?

Metodami badawczymi, którymi posługuje się autorka artykułu, są metoda analizy oraz metoda syntezy. Analiza dobranych treści umożliwiła podjęcie próby stworzenia pojęcia dramatu moralnego człowieka.

\section{CHARAKTERYSTYKA KLUCZOWYCH POJĘĆ}

Wskazane powyżej zagadnienia zostaną przedstawione w zakresie koniecznym dla wydobycia znaczenia dramatu moralnego człowieka, zwłaszcza w kontekście pedagogicznym.

Podstawowym pojęciem wymagającym odniesienia się jest pojęcie osoby. Mieczysław Rusiecki określa: „Osoba ludzka (gr. prosopon, łac. persona) to byt samoistny, rozumny, konkretny i doskonały. Zdanie «człowiek jest osobą» oznacza, że jest on kimś racjonalnym, obdarzonym możliwością intelektualnego poznania, a więc otwartym na prawdę. Dzięki tej możliwości nie tylko zdobywa szczegółową wiedzę o zjawiskach, ale również wykrywa ich cechy ogólne oraz prawidłowości (prawa, zasady) zachodzące między nimi. Następnie, systematyzuje wiedzę, 
tworzy naukę, zdobywając przy tej okazji wielorakie umiejętności i sprawności. Jest w stanie ująć całokształt osiągniętej wiedzy w ogólną wizję zwaną światopoglądem”. W rozumieniu Wincentego Granata „integralna osoba ludzka jest to jednostkowy, substancjalny i całkowity podmiot cielesno-duchowy, zdolny działać w sposób rozumny, dobrowolny i społeczny w celu harmonijnego ubogacenia siebie i ludzkości w zakresie całego bytu"2. Syntetyczne ujęcie osoby przedstawia miedzy innymi Alina Rynio pisząc, że „osoba jest kimś jedynym, niepowtarzalnym, kimś kto posiada «wnętrze», przeżywającym swoje czyny, doznania, a przede wszystkim swoją własną podmiotowość". ${ }^{3}$ Osoba ludzka jest kimś odrębnym, kimś kto jest obdarzony niezbywalną godnością, wolnością, rozumnością, kimś kto afirmuje się po przez miłość, kimś kto przeżywa siebie, swoje wnętrze i swoje czyny zewnętrzne, kimś, kogo cechuje „samoistność, samoświadomość, samookreślenie się (autodeterminacja), unikalność, oryginalność, inność, osobność (a więc niepowtarzalność), nieporównywalność, a także «niezastępowalność» (...) względem innej osoby i jej nieprzekazywalność"4. Osoba przeżywająca świadomie samą siebie wyraża się w niepowtarzalnym, swoistym „wymiarze” osobowości, którą można w określonym zakresie ujmować $\mathrm{w}$ pewne schematy i ramy. Biorąc pod uwagę jej funkcjonowanie na poziomie naturalnym i nadprzyrodzonym można zauważyć, że jej kształtowanie się przyjmuje swoisty charakter. Różnorodne sytuacje życiowe umożliwiają dostrzeżenie go również w perspektywie moralno-społecznej. Antoni Podsiad zauważa, że osobowość jest to „względnie trwała struktura ściśle ze sobą współdziałających, aktualnych i potencjalnych podukładów: somatycznego (konstytucja ciała), poznawczego (inteligencja z systemem poglądów i przekonań) oraz motywacyjno-emocjonalnego (potrzeby biologiczne, społeczne, psychologiczne, łącznie z systemem uznawanych wartości, postaw i ról społecznych) - integrowanych poprzez ośrodek własnych aktów psychicznych, zwanych ja"s.

${ }^{1}$ M. Rusiecki, Religijność a dojrzałość osobowa człowieka (wyzwanie dla polskiego nauczyciela na III tysiq̨clecie), w: T. Gumuła, T. Dyrda (red.), Kształcenie kandydatów na nauczycieli. Teoria - praktyka, Kielce 2006, s. 63.

${ }^{2}$ W. Granat, Osoba ludzka. Próba definicji, Lublin 2006, s. 293.

${ }^{3}$ A. Rynio, Integralne wychowanie w myśli Jana Pawła II, Lublin 2004, s. 33.

${ }^{4}$ M.A. Krąpiec, Człowiek jako osoba, Lublin 2005, s. 119.

${ }^{5}$ A. Podsiad, Słownik terminów i pojęć filozoficznych, Warszawa 2000, s. 602. 
W powyższym kontekście można przyjąć, że osobowość, pojmowana w kontekście personalistycznym, jest „zobowiązana” do nieustannego, dynamicznego stawania się dojrzałą, zintegrowaną jednostką osobową. Zobowiązanie to sprzyja aktualizacji własnej potencjalności rozwojowej. Dokonuje się ono na drodze uaktywnienia procesu integracji pozytywnej struktur ją konstytuujących. Stawanie się dojrzałej osobowości związane jest z osiąganiem doskonałości na drodze transgresyjnego przełożenia integracji umysłowo-wolitywnej i emocjonalnej na jakość moralną czynu. W tym względzie należy wydobyć znaczenie pojęcia integracji i integralnego rozwoju. Według Stefana Kunowskiego integracja jest całkowaniem rozwoju, który przyjmuje jakościową postać zwaną dojrzewaniem, „a polega on na całkowaniu, centralizowaniu zróżnicowanych dotychczas części składowych, które zaczynają się łączyć w całość, tworząc nowy układ rozwiniętych już składników”.6 Integralny rozwój można określić, jako „całościowy zewnętrzny i wewnętrzny rozwój człowieka i przystosowanie do życia według przyjętego wzoru"7, jakim jest pełnia człowieczeństwa. Krystyna Chałas twierdzi, że „Sprowadza się on do koordynacji i harmonii sfery fizycznej, psychicznej, duchowej i religijnej w projekcie życia, zdążającym do pełni człowieczeństwa. Wskaźnikiem tak rozumianego rozwoju jest spójność myśli, słowa i czynu zakotwiczona w dobru osobistym, integralnie związanym z dobrem wspólnym" ${ }^{\prime}$. Zatem, rozwój oznacza „proces doskonalenia się człowieka aż do osiągnięcia pełni człowieczeństwa" ${ }^{\prime \prime}$. Przebiega etapowo i obejmuje integralnie sprzężone ze sobą struktury osobowości takie, jak: biologiczną, psychologiczną, socjologiczną, kulturologiczną i światopoglądowo-duchową, religijną ${ }^{10}$. Sprzężenie to polega na tym, że wprowadzenie jednego elementu zmieniającego dotychczasowy układ jednej struktury (warstwy) powoduje zmiany w materii pozostałych struktur. Toteż, zastosowanie jednego bodźca w określonych uwarunkowaniach rozwojowych wobec jednej struktury powoduje kompleksowe reakcje zwrotne pozostałych struktur. Moment wprowadzenia elementu zakłócającego (pozytywnie bądź negatywnie) dotychczasowe funkcjonowanie tych struktur powoduje konflikt wewnętrzny,

${ }^{6}$ S. Kunowski, Podstawy współczesnej pedagogiki, Warszawa 2000, s. 184.

${ }^{7}$ K. Ostrowska, W poszukiwaniu wartości, Gdańsk 1994, s.14.

${ }^{8} \mathrm{~K}$. Chałas, Wychowanie ku wartościom wiejskim jako szansa integralnego rozwoju wychowanka, Lublin 2007, s. 11.

${ }^{9}$ S. Kunowski, Podstawy współczesnej pedagogiki, dz. cyt., s. 182.

${ }^{10}$ Zob. tamże, s. 193-203. 
który domaga się rozwiązania. Jego wymiar, natężenie i siła przeżycia dają o sobie znać na płaszczyźnie aksjologiczno-etycznej, czego wyrazem jest „wyraźne ugruntowanie się nowych wartości"11, a w konsekwencji ponowne odzyskanie jedności, lecz w innej, wyższej jakości ${ }^{12}$.

Ważnym czynnikiem wprowadzającym człowieka w tę nową jakość jest właściwie ukształtowane sumienie. Stanisław Gałkowski podkreśla, że stanowi ono „najwyższą instancję rozstrzygającą w sprawie decyzji moralnych"13. Zatem, można przyjąć, że sumienie warunkuje jakościowy przebieg rozwoju moralnego człowieka; inicjuje jego nową jakość życia poprzez umożliwienie mu doświadczenia dramaturgii wewnętrznych zmagań w przestrzeni dokonywanych rozstrzygnięć, wyborów i decyzji. Tę przestrzeń wewnętrzną można nazwać przestrzenią dramy, przestrzenią dramatu rozgrywającego się zawsze w człowieku, który pragnie osiągnąć swój ideał osobowościowy zgodnie z własną tożsamością moralną ${ }^{14}$. Darcia Narvaez i Daniel K. Lapsley zauważają, że moralna tożsamość osoby pojawia się wówczas, gdy kategorie moralne postępowania są fundamentalne, centralne i ważne dla zrozumienia samego siebie. Znajdują uzasadnienie w podejściu kognitywno-społecznym wskazującym na konieczność analizy przebiegu rozwoju moralnego ${ }^{15}$.

Aby czytelniej naświetlić tę wewnętrzną dramaturgię niejednokrotnie redukowaną $\mathrm{w}$ aspekcie zewnętrznych przejawów zachowań, zewnętrznych postaw, koniecznym jest uchwycenie adekwatnego rozumienia dramatu i dramy w ich immanentnym wymiarze. Krystyna Pankowska, pisząc o dramie, zauważa: „w każdym człowieku bowiem, w jego psychice, już od pierwszych lat życia, nieustannie odgrywa się naturalna drama wewnętrzna, improwizowany trening życiowy ról i sytuacji”"16. Drama wewnętrzna, w której „Ja” idealne w najgłębszej swojej istocie wchodzi w konflikt z „Ja” realnym, rodzi nowe doświadczenie, które podlega

${ }^{11}$ K. Dąbrowski, Osobowość i jej kształtowanie poprzez dezyntegrację pozytywnq, Warszawa 1975 , s. 45.

${ }^{12}$ Zob. tamże.

${ }^{13}$ S. Gałkowski, Rozwój i odpowiedzialność. Antropologiczne podstawy koncepcji wychowania moralnego, Lublin 2003, s. 218-221.

${ }^{14}$ Zob. D.K. Lapsley, D. Narvaez, Moral identity. Moral Functioning and the Development of Moral Character, w: D.M. Bartels, Ch.W. Bauman, L.J. Skitka, D.L. Medin (red.), „The Psychology of Learning and Motivation" 2009, Vol.50, s. 246.

${ }^{15}$ Tamże, s. 246-247.

${ }^{16}$ K. Pankowska, Edukacja przez dramę, Warszawa 1997, s. 7. 
wartościowaniu i osądowi moralnemu. W tym świetle ujęcie dramy przez autorkę wydaje się być adekwatne. Według niej „Drama to przede wszystkim swoisty sposób urzeczywistniania istoty człowieka, wyrażający się w nieustannej próbie życia, przebiegającej w ludzkiej psychice"17. Warto dodać, że drama, w szeroko rozumianym sensie, stanowi nieodzowny element, a nawet czynnik kreujący środowisko życia wewnętrznego człowieka. Jej transformacyjny charakter nasuwa konieczność zanurzenia się $\mathrm{w}$ refleksji nad własnym istnieniem $\mathrm{w}$ relacji dialogicznej nie tylko z samym sobą, ale z innymi, światem i Bogiem. Relacja ta wydobywa znaczenie dialogu w kształtowaniu środowiska życia wewnętrznego pod warunkiem, że jest on autentyczny. Janusz Kujawiński pisze: „autentyczny dialog jest najlepszą metodą kształtowania człowieka w człowieku"18. Romuald Łukaszyk podaje, że dialog to „rozmowa mająca na celu wzajemne konfrontacje i zrozumienie poglądów, a także współdziałanie w zakresie wspólnego poszukiwania prawdy, obrony wartości ogólnoludzkich i współpracy dla sprawiedliwości społecznej i pokoju. Zakłada uznanie godności i wolności każdego człowieka i jego prawa do wyrażania własnych poglądów (nawet obiektywnie błędnych) z racji światopoglądowego pluralizmu, wolności sumienia i religii oraz tolerancji"19. Umiejętność prowadzenia dialogu personalistycznego na każdej płaszczyźnie życia owocuje konstruktywnie dokonującymi się zmianami, które można określić, jako wartościowe.

Zgodnie z powyższym można przyjąć, że drama, rozumiana w kontekście aksjologiczno-etycznym, staje się konstruktywno-twórczym nośnikiem wartościowych treści wówczas, gdy dialog w niej stosowany przyjmuje postać edukacyjną (a nade wszystko wychowującą), a jej uczestnicy poddają te treści refleksyjnej analizie. Refleksja ${ }^{20}$ towarzysząca dramie ubogaca każdego z nich, co wydaje się uzasadnione w świetle jej ujęcia przez autorkę niniejszego artykułu. Zgodnie z nim, „refleksję można określić, jako wewnętrzny, aktywny, dynamiczny proces obejmujący człowieka w jego integralnej strukturze. Proces ten ujawnia jakość tej struktury w czynie osoby, który zakorzeniony jest w konkretnym doświadczeniu mającym miejsce w konkretnym czasie. Wiedza płynąca z tego doświadczenia,

17 Tamże, s. 32.

${ }^{18}$ J. Kujawiński, Ewolucja szkoły i jej współczesna wizja, Poznań 2010, s. 63.

${ }^{19}$ R. Łukaszyk, Encyklopedia katolicka, t. 3, Lublin 1989, s. 1258.

${ }^{20}$ Zob. J. Amulya, What is Reflective Practice?, w: „Community Science”, Gaithersburg, MD 20877, May 2011, s. 1-5. 
któremu towarzyszy refleksja wymaga odpowiedniego ukształtowania i takiego ukierunkowania, by służyła osobistemu i społecznemu dobru i stymulowała proces wzrastania człowieka ku pełni jego człowieczeństwa"21.

Tak pojmowana refleksja wpisuje się $\mathrm{w}$ istotę dramy. $\mathrm{W}$ podejściu pragmatyczno-aksjologicznym, może pełnić funkcję kontrapunktu, uaktywniającego i dynamizującego integralny rozwój osoby. Drama znamionująca się refleksyjnością umożliwia dotarcie do "jądra” samego siebie, do głębi doświadczenia samego siebie wobec własnych przekonań, sądów itd. Grażyna Zielińska pisze: „Drama wymaga refleksji, namysłu, czasu na kontemplację, na dialog z samym sobą. Bezruch też jest formą ruchu. W sytuacji przeżywania dramy wewnętrznej, swojego osobowego «Teatru Wnętrza», w indywidualnych zmaganiach w rozwiązywaniu konfliktów niezbędne są spokój, rozciągnięcie w czasie, spowolnienie. Zatrzymanie-trwanie wydaje się wręcz niezbędne. Dla dramy i jej celów najważniejsze jest doprowadzenie do intencjonalnych wyborów dobra, które wymagają namysłu, przeżyć, emocji. Dlatego głębokie warstwy życia emocjonalnego dają większą szansę do większego uwydatnienia się intencjonalnego charakteru odnośnych przeżyć"22. Tego rodzaju dramowa intencjonalność, zakorzeniona w postępowaniu moralnym człowieka ${ }^{23}$, może stanowić jeden z czynników determinujących wychowanie moralnego sumienia. To, jak jest ono uformowane, zapewne nie pozostaje bez znaczenia dla immanentnie przeżywanego dialogicznego spotkania z sobą samym, co zostanie naświetlone przy analizie koncepcji integralnego rozwoju według K. Wojtyły.

Głębsze, analityczne podejście do dramy implikuje konieczność zatrzymania się nad słowem dramat. Encyklopedia Powszechna podaje różne rozumienia dla określenia pojęcia dramatu w jego odsłonach: literackiej, liturgicznej, muzycznej i satyrycznej. Istotnym elementem pojęcia dramatu jest jego literackie ujęcie: „operuje dialogiem jako podstawową formą podawczą: jako tekst dramat pozostaje częścią literatury, natomiast w realizacji scenicznej, stanowiąc jej element podstawowy, należy do świata teatru; od epiki i liryki różni się realną nieobecnością nadrzędnego podmiotu literackiego oraz pełną autonomią wypowiedzi

${ }^{21}$ Zob. M. Szymańska, Transformative creativity in teacher formation. A pedagogical approach, Kraków 2017, s. 130.

${ }^{22}$ G. Zielińska, Filozofia dramy w procesie twórczym, t. 1. Kraków 2013, s. 29.

${ }^{23}$ S. Kunowski, Wartości w procesie wychowania, Kraków 2003, s. 46. 
i działań postaci; strukturę językową dramatu tworzą: tekst główny (dialogi i monologi postaci) oraz tekst poboczny, tzw. didaskalia"24.Takie ujęcie dramatu wydaje się być w pewien sposób kompatybilne z powyżej ukazanym rozumieniem dramy, jej znaczeniem dla integralnego rozwoju człowieka. Osadzenie takich elementów, jak: dialog, monolog, treść, teatr, przekaz „poboczny” czy autonomia w refleksji nad doświadczeniem przeżywanym przez osobę w konkretnej sytuacji życiowej niejednokrotnie wywołuje dylemat moralny. Ujęcie go w kategorii dramatu ułatwia podjęcie się próby stworzenia interdyscyplinarnej definicji dramatu moralnego człowieka, umocowanej w powyższym rozumieniu dramy. Drama bowiem, pojmowana na gruncie aksjologicznym, etycznym, pedagogicznym czy też psychologicznym, stanowi ważny punkt odniesienia do dramatu moralnego człowieka. Dramat moralny pojawia się, gdy człowiek doświadcza sytuacji dramowych w dokonywanych wyborach, podejmowanych decyzjach i spełnianym czynie, który angażuje emocje, wolę i intelekt.

W świetle powyższych treści zostało przyjęte, że dramatem moralnym człowieka jest dialogiczno-monologiczna dramowa aktywność „teatru wnętrza”, uwarunkowana biologicznie, psychicznie, społeczno-etycznie, kulturowo i duchowo. Podlega ona procesowi doskonalenia, którego jakość uwarunkowana jest właściwie ukształtowanym moralnie sumieniem. Procesowi temu towarzyszy głęboka refleksja nad doświadczeniem samego siebie w relacji do innych, świata i Boga. Sens tak sformułowanego dramatu moralnego zostanie ukazany w analizie koncepcji integralnego rozwoju osoby według Karola Wojtyły.

\section{DRAMAT MORALNY CZŁOWIEKA W ŚWIETLE KONCEPCJI INTEGRALNEGO ROZWOJU OSOBY WEDŁUG K. WOJTYŁY}

Koncepcja integralnego rozwoju osoby według K. Wojtyły kryje w sobie niewyczerpujące się bogactwo przestrzeni dramowej, gdzie rozgrywa się dramat moralny człowieka. Wydobywa ona interdyscyplinarny aspekt rozumienia kim jest osoba, co się w niej dzieje, z nią dzieje i przez nią dzieje w sposób świadomy, podświadomy i nieświadomy. Jej fundamentalny, fenomenalny i immanentny wymiar znajduje odzwierciedlenie w publikacji Osoba i czyn autora, który ukazuje w niej zwrotny, dwukierunkowy przebieg progresji rozwojowej osoby, „która przez czyn

${ }^{24}$ M. Karolczuk-Kędzerska (red.), Encyklopedia Powszechna, t. 2, 2003, s. 322. 
się ujawnia"25. W niej to jednocześnie dokonuje się transformacja dotychczasowych przekonań, postaw kształtujących obraz światopoglądowy osoby na siebie, innych ludzi i świata, na drodze doświadczenia wewnętrznego i zewnętrznego, podlegającego internalizacji. Przestrzeń, w której dokonuje się ta transformacja stanowi pewnego rodzaju „scenę” autentycznego teatru życia, którego punktem centralnym jest rozgrywający się hybrydowo dramat moralny człowieka. Tu już nie ma miejsca na zakładanie masek życiowych ról, tu dokonuje się „stawanie”pojawia się „suppositum”, co wyraża właśnie koncepcja integralnego rozwoju według K. Wojtyły.

Autor podaje: „Człowiek jako osoba jest ukonstytuowany w znaczeniu metafizycznym jako byt poprzez własne suppositum: jest tym, który od początku istnieje i działa, chociaż działanie w pełni ludzkie (actus humanus), czyli czyn, pojawia się dopiero na pewnym etapie jego rozwoju" ${ }^{26}$. Wtedy to dochodzi do pewnej synchronizacji psychiczno-duchowej, społeczno-kulturowej osoby z czynem, rozumianym w kontekście dokonującej się integracji, posiadającej złożony charakter ${ }^{27}$. Karol Wojtyła pisze: „Czyn ludzki zawiera w sobie wielość i różnorodność dynamizmów właściwych somatyce oraz psychice, i właśnie w stosunku do nich stanowi nadrzędną dynamiczną jedność. Na tym polega integracja osoby w czynie - integracja jako aspekt komplementarny w stosunku do transcendencji"28 umożliwiającej przejście „granicy pomiędzy «dzianiem się» a «działaniem»"29, czego egzemplifikacją może być analiza dramatu moralnego człowieka dokonana w dziele Brat naszego Boga ${ }^{30}$.

Rozumienie koncepcji integralnego rozwoju człowieka w powyższym świetle sprzyja głębszemu, krytycznemu i konstruktywnemu poznaniu siebie, drugiego człowieka, świata oraz odkrywaniu na nowo Tajemnicy Bożej Miłości. Dokonuje się ono poprzez przeżywanie dramatu moralnego własnego „bycia” „tu” i „teraz” w perspektywie wieczności i zbawienia. Biorąc pod uwagę aspekt transformacji moralnej, rozumianej jako proces progresywnie dokonujących się przemian

\footnotetext{
${ }^{25}$ K. Wojtyła, Osoba i czyn oraz inne studia antropologiczne, Lublin 2000, s. 338.

${ }^{26}$ Tamże, s. 380.

27 Tamże, s. 231.

${ }^{28}$ Tamże, s. 237.

${ }^{29}$ Tamże, s. 239.

${ }^{30}$ Zob. K. Wojtyła, Brat naszego Boga, Warszawa 2003.
} 
rozwojowych ${ }^{31}$, pozwala dostrzec przestrzeń dramaturgii dojrzewania moralnego Brata Alberta. Stopniowo staje się on Chrystusowym odbiciem miłości wobec bliźnich napotykanych na swej drodze. Malując portret Chrystusa zatytułowany: Ecce Homo, dramatycznie maluje Jego wizerunek w swoim człowieczeństwie. Boleśnie zmierza się z doświadczeniem własnej małości i jednocześnie z ogromną siłą pragnienia, by przekazać jak najlepiej swój wewnętrzny, dialogiczny wymiar spotkania z Bogiem innym ludziom. W sposób dramowy przeżywa siebie, swoje czyny na poziomie struktury somatyczno-wegetatywnej, psycho-emotywnej, duchowej i społecznej, co jest zgodne z koncepcją integralnego rozwoju według Karola Wojtyły.

Odnosząc się do pierwszej struktury, trzeba zauważyć, że pomimo zmian dokonujących się w organizmie człowieka w ciągu całego życia „osoba nie może być utożsamiana z ciałem" ${ }^{\prime 2}$. Z racji swej tożsamości zobowiązana jest do panowania nad nim, nad swoimi popędami, których dynamika urzeczywistnia się „w czynie i poprzez $\mathrm{czyn}^{\prime \prime 3}$.W strukturze somatyczno-wegetatywnej rozgrywa się fundamentalny dramat moralny najpierw na poziomie rozstrzygania, następnie wyboru i decyzji skutkujących w działaniu i konsekwencjach tego działania. Zasięg tego dramatu, czy też jego horyzont, zdeterminowany jest rozumieniem prawdy, dialektyczną interpretacją rzeczywistości, logiczną argumentacją i krytycznym myśleniem $^{34}$. Pojawia się tu znaczenie świadomości i samoświadomości własnego ciała. Jak bowiem podaje Karol Wojtyła: „Człowiek w szczególny sposób uświadamia sobie, że je posiada, gdy w działaniu posługuje się nim jako posłusznym środkiem ekspresji dla swego samostanowienia"35, co wiąże się z koniecznością wzięcia pod uwagę jego reaktywności i żywotności ${ }^{36}$. Niejednokrotnie stanowi to przedmiot jego dramatycznej refleksji nad sensem życia.

Z jednej strony konstruktywnie przeżywa siebie jako podmiotowe „ja”, jako suppositum, mając świadomość jedności z własnym ciałem, z drugiej „boryka się”

${ }^{31}$ Zob. W. McWhinney, L. Markos, Transformative Education. Across the Threshold, „Journal of Transformative Education" 2003, Vol. 1, No 1, s. 20-32.

${ }^{32} \mathrm{~K}$. Wojtyła, Osoba i czyn oraz inne studia antropologiczne, dz. cyt., s. 245.

${ }^{33}$ Tamże, s. 245.

${ }^{34}$ Zob. D. Willingham, Critical Thinking: Why Is It So Hard to Teach?, „American Educator" 2007, s. 10, www.aft.org/sites/default/files/periodicals/Crit_Thinking.pdf (dostęp: 10. 09.2016 r.).

${ }^{35} \mathrm{~K}$. Wojtyła, Osoba i czyn oraz inne studia antropologiczne, dz. cyt., s. 247.

${ }^{36}$ Zob. tamże, s. 246-250. 
z problemem własnej sprawczości na poziomie funkcjonowania instynktu i popędliwości, zwłaszcza w zakresie czucia, odczucia cielesnego i wyobrażeń zmysłowych. Niekontrolowane i „niewychowane” wyobrażenia „napędzane wyobraźnią" stanowią przeszkodę w rozwoju człowieka, zwłaszcza rozwoju moralnego. Dlatego tak ważnym jest ich wychowanie i reagowanie na nie na poziomie wrażliwej struktury psychiczno-emotywnej, odzywające się wtedy, gdy wegetacja, „a wraz z nią całe fizyczne istnienie (istnienie „w ciele”), są zagrożone”37. Czucie i odczucie tego zagrożenia odbierane jest w szczególny sposób. Zbagatelizowanie wewnętrznych symptomów i poruszeń ostrzegających przed czymś rozpoznawanym intuicyjnie, jako negatywnym, może skutkować bolesnym doświadczeniem zła moralnego wywołującego niepotrzebne napięcia sprzyjające dezintegracji osobowości ${ }^{38}$. Oddziałuje na czynnik emotywności oraz woli, która „przez rozstrzygnięcie czy wybór stanowi zawsze określoną poznawczo, umysłowo odpowiedź na wartości” ${ }^{39}$. Z tego powodu zachowanie czujności wobec „poruszeń", jakie pojawiają się w człowieku, może stanowić swoiste antidotum na „czyhające” wewnątrz i na zewnątrz moralne zło. Uaktywniająca się gotowość do walki wewnętrznej o prawdę i dobro, umożliwia sumieniu spełnianie jego funkcji. Biorąc pod uwagę ten fakt, warto pamiętać, że emotywność oznacza „swoistą wrażliwość na wartości”40 i ułatwia głębsze zrozumienie, czym jest transcendencja osoby w czynie ${ }^{41}$. Właściwie wychowana emotywność wzmacnia dojrzałość woli w czynieniu dobra, nadaje przestrzeni dramowej konstruktywno-twórczy charakter, sprzyja budowaniu postawy otwartości na Transcendencję. Emotywność w postępowaniu Adama Chmielowskiego otwierała go coraz bardziej na wezwanie głosu Bożej miłości ku służbie najuboższym. Bez wrażliwości na wartości nie potrafiłby na nie konkretnie odpowiedzieć, nie byłby w stanie dojrzale pełnić misję caritas.

Przedstawienie struktury duchowej wiąże się ściśle z koniecznością podkreślenia znaczenia wspomnianej transcendencji. Jest ona istotnym czynnikiem integracji osoby w czynie, jej wolności, powinności, odpowiedzialności i prawdy. Oznacza przekraczanie jakiejś granicy czy progu w dwóch wymiarach (podaje

37 Tamże, s. 257.

${ }^{38}$ Zob. K. Dąbrowski, Osobowość i jej kształtowanie poprzez dezyntegrację pozytywna, dz. cyt.

${ }^{39} \mathrm{~K}$. Wojtyła, Osoba i czyn oraz inne studia antropologiczne, dz. cyt., s. 267.

${ }^{40}$ Tamże.

${ }^{41}$ Tamże, s. 275. 
dwa ujęcia transcendencji) poziomym i pionowym. Transcendencja pozioma jest intencjonalnym przekraczaniem "granicy podmiotu ku przedmiotowi”"42; transcendencja pionowa zaś jest przede wszystkim transcendencją osoby w czynie, która dokonuje się „przez sam fakt wolności, bycia wolnym w działaniu, a nie tylko przez intencjonalne skierowanie chcenia w stronę właściwego im przedmiotu, wartości - celu" ${ }^{\prime 3}$. Zatem przez czyn ujawnia się zdolność człowieka do ujmowania prawdy; rozróżnienia tego, co jest prawdą a co nią nie jest, nawet gdy przybiera postać prawdy. Autor zaznacza: „Człowiek nie jest tylko biernym zwierciadłem, które odbija przedmioty, ale zachowuje w stosunku do nich swoistą nadrzędność przez prawdę; jest to «wyższość prawdy» związana z pewnym jakby dystansem do przedmiotów, która wpisana jest w duchową naturę osoby"44. Świadomość znaczenia prawdy w ocenie prawdziwości przeżyć i doświadczeń kształtuje postawę czujności wobec ich autentyczności, wyzwalając poczucie odpowiedzialności i szczęśliwości w spełnianiu siebie i urzeczywistnianiu dobra, które go czyni dobrym ${ }^{45}$. Dokonuje się ono stopniowo podczas pokonywania wielu przeszkód i trudności.

\section{Postępowanie oparte na prawdzie i pragnieniu czynienia dobra zarówno wewnętrznego, jak i zewnętrznego wymaga niejednokrotnie samozaparcia, pokory i ofiary - jak to miało miejsce w przypadku postępowania Karola Wojtyły, Adama Chmielowskiego, Maksymiliana Kolbe i wielu innych.}

Jego istotę można odczytać w przeżyciu duszy, które „nie ogranicza się do samych tych treści z właściwym im uwewnętrznieniem w człowieku, ale ogarnia w nich i poprzez nie jakby całe duchowe «ja» człowieka" ${ }^{46}$. Przeżycie duszy

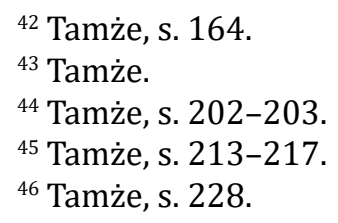


kryje w sobie to, co duchowe i cielesne zintegrowane w potencjalno-transcendentalnym Bycie osobowym. Obejmuje też Bycie dla innych w urzeczywistnianiu miłości społecznej, miłości bliźniego, określonej miłością Boga do człowieka. Zawiera w sobie całą dramaturgię życia, czego egzemplifikacją jest proces tworzenia wizerunku Chrystusa w Ecce Homo kontemplowanego przez artystę w jego wnętrzu.

Wyrazem tej dramowej kontemplacji jest spotkanie wewnętrzne poety z Chrystusem opisane w Pieśni o Bogu ukrytym: „Miejsce moje jest w Tobie. Twoje miejsce jest we mnie. Jest to wszakże miejsce wszystkich ludzi. A przecież nie jestem na nim pomniejszony przez wszystkich. Jestem bardziej sam (niż gdyby nie było nikogo innego); jestem sam na sam. I zarazem jestem przez wszystkich pomnożony w Krzyżu, który na tym miejscu stał. To pomnożenie - a nie - pomniejszenie - pozostaje tajemnicą: Krzyż idzie pod prąd. Cyfry cofają się w nim przed Człowiekiem" ${ }^{\prime 4}$. Nasycenie tego spotkania ma miejsce w Misterium Narodzenia i Zmartwychwstania Chrystusa, w bogactwie doświadczania i przeżywania cierpienia i chwały, we współuczestniczeniu z Nim i w Nim, z innymi i dla innych. Ono właśnie wskazuje na dramaturgię „teatru wnętrza”, na transcendentny wymiar przestrzeni dramowej, dzięki której można:

- znaleźć sens tego, co wydaje się pozornie bez sensu;

- odnaleźć i uchwycić się nadziei w sytuacji, gdy wszystko zaprzecza jej obecności; wskazać na miłość społeczną wbrew nienawiści i okrucieństwa;

- znaleźć „skrawek nieba” w doświadczaniu „wszech-otaczającego” piekła, jakim były na przykład obozy koncentracyjne.

W takim kontekście, dostrzeżenie wagi dojrzale uformowanej struktury społecznej osoby człowieka, wydaje się być uzasadnione. Struktura społeczna osobowego funkcjonowania człowieka rozwija się i doskonali właśnie w uczestnictwie z „ innymi” w budowaniu wspólnoty ${ }^{48}$, której najwyższą wykładnią wartości jest wspólne wcielanie w życie przykazania ewangelicznej miłości. Przykazanie to jest zarówno normą osobową, jak i społeczną, a jej urzeczywistnienie w czynie uzasadnione jest faktem, iż człowiek bytuje z innymi ludźmi, nawiązuje z nimi relacje, spełnia się dzięki uczestnictwu w życiu wspólnoty współdziałając

${ }^{47}$ K. Wojtyła, Pieśń o Bogu ukrytym, Kraków 1998, s. 76.

${ }^{48}$ Zob. M. Szymańska, Miłość wychowawcza, w: K. Chałas, A. Maj (red.), Encyklopedia Aksjologii Pedagogicznej, Radom 2016, s. 602. 
z innymi. Karol Wojtyła twierdzi, że „przez uczestnictwo rozumiemy tutaj to, co odpowiada transcendencji osoby w czynie wówczas, gdy ten czyn jest spełniany «wspólnie z innymi» (...). Jeśli odpowiada transcendencji, odpowiada także integracji osoby w czynie" ${ }^{\prime 9}$. Dzięki tak pojmowanemu uczestnictwu człowiek zachowuje swą indywidualność, ubogacając nią wspólnotę ${ }^{50}$, która jednocześnie stwarza warunki dla coraz lepszego jego rozwoju, a tym samym do własnego rozwoju. W takim kontekście funkcja communionis aedificatio miłości wychowawczej ${ }^{51}$ ma szansę być realizowana. Ona to nadaje uczestnictwu wymiaru personalistycznego.

Autentyczne uczestnictwo osoby w życiu wspólnoty nasuwa potrzebę budowania w niej i z nią postawy solidarności, konstruktywnego sprzeciwu, dialogu odrzucającego konformizm i postawę uniku. Solidarność, jak zauważa autor, „oznacza stałą gotowość do przyjmowania i realizowania takiej części, jaka każdemu przypada w udziale z tej racji, że jest członkiem określonej wspólnoty"52. Granice podejmowanych i realizowanych działań powinny być określone zakresem obowiązków, odpowiedzialnie i rzetelnie spełnianych, bez „przerzucania” ich na innych członków wspólnoty. Obroną dla negatywnych zachowań pojawiających się w niej jest dojrzale okazywana postawa sprzeciwu. Ujawnia ona jakość rozgrywającego się dramatu moralnego w sercu pojedynczego człowieka i sercu wspólnoty, którą on współtworzy. Karol Wojtyła pisze, że „Wspólnota ludzka wtedy posiada prawidłową strukturę, kiedy słuszny sprzeciw nie tylko ma w niej prawo obywatelstwa, ale także taką skuteczność, jakiej dopomaga się dobro wspólne z prawem uczestnictwa"53. Aby słuszny sprzeciw mógł zaowocować autentycznym dobrem, niezbędne jest podjęcie dialogu, który nie unika napięć, konfliktów, walk, ale wykazuje się dążeniem do realizacji tego, co słuszne i prawdziwe. Każdy z uczestników dialogu doświadcza sytuacji dramowej, która posiada swoją wartość i nie może pozostać bez echa dla budowania relacji opartych na jedności wspólnoty. Doświadczenie budowania jej z innymi pogłębia świadomość poznawania siebie, innych ludzi, świata i Boga. Podlega pozytywnej, klaryfikującej redukcji, która jest jasnym, sprecyzowaniem celu realizacji projektu życiowego

\footnotetext{
${ }^{49} \mathrm{~K}$. Wojtyła, Osoba i czyn oraz inne studia antropologiczne, dz. cyt., s. 309.

${ }^{50}$ Tamże, s. 316.

${ }^{51}$ Zob. M. Szymańska, Miłość wychowawcza, art. cyt., s. 602.

${ }^{52} \mathrm{~K}$. Wojtyła, Osoba i czyn oraz inne studia antropologiczne, dz. cyt., s. 323.

${ }^{53}$ Tamże, s. 325.
} 
w skali mikro- i makrospołecznej, co zostało odzwierciedlone w działalności Karola Wojtyły czy Adama Chmielowskiego - głównego bohatera dramatu pt. Brat naszego Boga.

\section{W rozgrywającym się dramacie wewnętrznym człowiek przeżywa, mniej lub bardziej świadomie, bycie sprawcą tego, co się dzieje za jego przyczyną.}

Autor podaje, że: „jedną postacią dynamizmu człowieka jest ta, w której on sam występuje jako sprawca, czyli jako świadoma swego przyczynowania przyczyna - i tę postać określamy w zdaniu «człowiek działa». Drugą postacią dynamizmu człowieka jest ta, w której człowiek nie jest świadom swojej sprawczości, nie przeżywa jej - i tę postać określamy zdaniem « (coś) dzieje się w człowieku" ${ }^{54}$. Te dwie postacie dynamizmu człowieka pozostają w pewnej korelacji, która w układzie cyrkularnym pozwala się wyjaśnić, wskazując na dynamizm jego twórczej sprawczości. Stając się twórcą swego działania, a więc twórcą swego czynu, ma on wpływ na kształt wewnętrznej przestrzeni dramowej, która umożliwia mu spotkanie z sobą, drugim człowiekiem i Bogiem.

\section{ZAKOŃCZENIE}

Koncepcja integralnego rozwoju człowieka według Karola Wojtyły wydobywa szczególne znaczenie moralno-duchowego „stawania się” człowieka w świetle aktualizacji jego potencjalności rozwojowej. Pojawiający się dramat moralny w przestrzeni dramowej niejednokrotnie dotyczy wyboru tego, co jest dobre lub złe. W niej podejmowane są konkretne decyzje, co do urzeczywistniania wartości materialnych i niematerialnych w obliczu prawdy i prawości. Ona to staje się źródłem stymulującym postawę gotowości do ponoszenia skutków postępowania $\mathrm{w}$ aspekcie odpowiedzialności. Umożliwia świadome przeżywanie siebie, jako podmiotu, sprawcy i twórcy czynu. Stawia wyzwania moralne dla człowieka.

${ }^{54}$ Tamże, s. 114.

KULTURA - MEDIA - TEOLOGIA 32/2018 
Od tego, jak zostaną one podjęte, zależy jego poczucie: szczęśliwości (jak to ujmuje Karol Wojtyła), spełnienia lub przegranej. Tu ujawnia się afirmacja godności człowieka na poziomie indywidualnym i społecznym. W niej doświadcza on swego dramatu moralnego we własnym „teatrze wnętrza, w którym główną rolę gra jego moralne sumienie. Dzięki niemu ma szansę pokonać samego siebie na drodze integralnego rozwoju.

\section{BIBLIOGRAFIA}

Amulya J., What is Reflective Practice?, w: „Community Science”, Gaithersburg, MD 20877, May 2011.

Chałas K., Wychowanie ku wartościom wiejskim jako szansa integralnego rozwoju wychowanka, Lublin 2007.

Dąbrowski K., Osobowość i jej kształtowanie poprzez dezyntegrację pozytywną, Warszawa 1975.

Gałkowski S., Rozwój i odpowiedzialność. Antropologiczne podstawy koncepcji wychowania moralnego, Lublin 2003.

Granat W., Osoba ludzka. Próba definicji, Lublin 2006.

Karolczuk-Kedzierska M. (red. nacz.), Encyklopedia Powszechna, t. 2, Kraków 2003.

Krąpiec M.A., Człowiek - dramat natury i osoby, w: F. Adamski (red.), Wychowanie personalistyczne, Kraków 2005, s. 23-40.

Krąpiec M.A., Człowiek jako osoba, Lublin 2005.

Kujawiński J., Ewolucja szkoły i jej współczesna wizja, Poznań 2010.

Kunowski S., Podstawy współczesnej pedagogiki, Warszawa 2000.

Kunowski S., Wartości w procesie wychowania, Kraków 2003.

Łukaszyk R., Dialog, w: Encyklopedia katolicka, t. 3, Lublin 1989, s. 1258.

McWhinney W., Markos L.. Transformative Education. Across the Threshold, „Journal of Transformative Education" 2003, Vol 1, No 1, s. 20-32.

Narvaez D., Lapsley K., Moral identity. Moral Functioning and the Development of Moral Character, w: D.M. Bartels, Ch.W. Bauman, L.J. Skitka, D.L. Medin (red.), The Psycholgy of Learning and Motivation, Vol. 50, Burlington 2009, s. 237-273.

Ostrowska K., W poszukiwaniu wartości, Gdańsk 1994.

Pankowska K., Edukacja przez dramę, Warszawa 1997.

Pankowska K., Pedagogika dramy. Różne zakresy pojęcia, Warszawa 2000.

Podsiad A., Stownik terminów i pojęć filozoficznych, Warszawa 2000.

Rusiecki M., Religijność a dojrzałość osobowa człowieka (wyzwanie dla polskiego nauczyciela na III tysiąclecie), w: T. Gumuła, T. Dyrda (red.), Kształcenie kandydatów na nauczycieli. Teoria - praktyka, Kielce 2006, s. 61-83.

Rynio A, Integralne wychowanie w myśli Jana Pawła II, Lublin 2004.

Szymańska M., Uczestnictwo $w$ życiu społecznym $w$ świetle teorii uczestnictwa Karola Wojtyły - Jana Pawła II. Kontekst pedagogiczny, „Artes Liberales” 2011, nr 1-2, s. 29-50. 
Szymańska M., Miłość wychowawcza, w: K. Chałas, A. Maj (red.), Encyklopedia Aksjologii Pedagogicznej, Radom 2016, s. 599-604.

Szymańska M., Transformative creativity in teacher formation. A pedagogical approach, Kraków 2017.

Wojtyła K., Brat naszego Boga, Warszawa 2003.

Wojtyła K., Osoba i czyn, Lublin 2000.

Wojtyła K., Pieśń o Bogu ukrytym, Kraków 1998.

Zielińska G., Filozofia dramy w procesie twórczym, t. I, Kraków 2013.

\section{Biogram}

Maria Szymańska, adiunkt w Katedrze Andragogiki i Aksjologii Pedagogicznej Akademii Ignatianum w Krakowie; Prezes Towarzystwa Naukowego „Educare”; członek: Institute of Sustainable Education, Baltic\&Black Sea Circle Consortium; Zespołu Redakcyjnego „Edukacja Elementarna. W Teorii i Praktyce”; „Multidisciplinary Journal of School Education”; advisory board „Training and Practice Journal of Educational Sciences” (Hungary). Adres e-mail: mariaszymanska59@gmail.com 